\title{
Article \\ The Effects of Three Chlorhexidine-Based Mouthwashes on Human Osteoblast-Like SaOS-2 Cells. An In Vitro Study
}

\author{
Giulia Brunello ${ }^{1,2,+}\left(\mathbb{D}\right.$, Kathrin Becker ${ }^{3, *,+}+\mathbb{D}$, Luisa Scotti ${ }^{1,4}$, Dieter Drescher ${ }^{3}$, Jürgen Becker ${ }^{1}(\mathbb{D}$ and \\ Gordon John ${ }^{1}$ (])
}

1 Department of Oral Surgery, University Clinic of Düsseldorf, 40225 Düsseldorf, Germany; giulia.brunello@med.uni-duesseldorf.de (G.B.); luisa.c.scotti@gmail.com (L.S.); juergen.becker@med.uni-duesseldorf.de (J.B.); gordon.john@med.uni-duesseldorf.de (G.J.)

2 Department of Neurosciences, University of Padua, 35128 Padua, Italy

3 Department of Orthodontics, University Clinic of Düsseldorf, 40225 Düsseldorf, Germany; dieter.drescher@med.uni-duesseldorf.de

4 Dental Practice, 46147 Oberhausen, Germany

* Correspondence: kathrin.becker@med.uni-duesseldorf.de; Tel.: +49-211-8118145

+ The authors contributed equally.

Citation: Brunello, G.; Becker, K.; Scotti, L.; Drescher, D.; Becker, J.; John, G. The Effects of Three Chlorhexidine-Based Mouthwashes on Human Osteoblast-Like SaOS-2 Cells. An In Vitro Study. Int. J. Mol. Sci. 2021, 22, 9986. https:// doi.org/10.3390/ijms22189986

Academic Editor: Feng-Huei Lin

Received: 29 July 2021

Accepted: 13 September 2021

Published: 15 September 2021

Publisher's Note: MDPI stays neutral with regard to jurisdictional claims in published maps and institutional affiliations.

Copyright: (c) 2021 by the authors. Licensee MDPI, Basel, Switzerland. This article is an open access article distributed under the terms and conditions of the Creative Commons Attribution (CC BY) license (https:// creativecommons.org/licenses/by/ $4.0 /)$

\begin{abstract}
Several decontamination methods for removing biofilm from implant surfaces during surgical peri-implantitis treatment have been reported, including the intraoperative usage of chlorhexidine (CHX)-based antiseptics. There is a lack of information on possible adverse effects on bone healing. The study aimed to examine the impact of three CHX-based mouthwashes on osteoblast-like cells (SaOS-2) in vitro. Cells were cultured for three days in 96-well binding plates. Each well was randomly treated for either 30,60 or $120 \mathrm{~s}$ with $0.05 \% \mathrm{CHX}$ combined with $0.05 \%$ cetylpyridinium chloride (CPC), $0.1 \% \mathrm{CHX}, 0.2 \% \mathrm{CHX}$ or sterile saline $(\mathrm{NaCl})$ as control. Cell viability, cytotoxicity and apoptosis were assessed at day 0,3 and 6. Cell viability resulted in being higher in the control group at all time points. At day 0 , the $\mathrm{CHX} 0.2$ group showed significantly higher cytotoxicity values compared to CHX 0.1 (30 s), CHX + CPC (30 s, $60 \mathrm{~s}$ and $120 \mathrm{~s}$ ) and control (60 s and $120 \mathrm{~s}$ ), while no significant differences were identified between $\mathrm{CHX}+\mathrm{CPC}$ and both $\mathrm{CHX} 0.1$ and $\mathrm{NaCl}$ groups. All test mouthwashes were found to induce apoptosis to a lower extent compared to control. Results indicate that $0.2 \% \mathrm{CHX}$ presented the highest cytotoxic effect. Therefore, its intraoperative use should be carefully considered.
\end{abstract}

Keywords: antiseptic; bone; cetylpyridinium chloride; chlorhexidine; mouthrinse; peri-implantitis; periodontitis

\section{Introduction}

Peri-implantitis is a multifactorial bacteria-induced pathology affecting the periimplant tissues, leading to a progressive reduction of the supporting bone and, subsequently, to implant loss if left untreated [1,2].

While a non-surgical mechanical debridement might be resolutive in the case of peri-implant mucositis, it seems to have limited efficacy for the management of periimplantitis [3,4]. Although the non-surgical approach represents a fundamental step in the initial treatment of peri-implantitis, in cases of recurrence of bleeding and suppuration, it has to be followed by surgical therapy, which allows a better access for an effective removal of the biofilm from the contaminated implant surfaces [5]. To this aim, several mechanical and chemical techniques have been proposed; however, no particular decontamination protocol has been demonstrated to be superior [5-7].

Mouthwashes can be used as adjunctive measures to the mechanical elimination of bacteria through surgical debridement [8]. Among these, chlorhexidine (CHX) is one of the most commonly used products due to its high antibacterial properties [5,9]. However, its 
beneficial effect is controversial. In a randomized controlled clinical trial on the surgical treatment of advanced peri-implantitis, a $0.2 \%$ solution of chlorhexidine digluconate did not exhibit any beneficial effect over the mechanical implant surface decontamination alone at both 1- and 3-year follow-up [10,11]. This is consistent with previous findings in animal models [12]. Furthermore, socket rinsing with CHX has also been proposed, but its effect is still controversial, as some authors reported impairment of wound healing while others reported a reduced rate of alveolitis [13,14].

Several concerns have been raised regarding the potential tissue toxicity of these agents. Numerous studies have investigated the cytotoxicity of CHX on different cells, including fibroblasts, osteoblasts, myoblasts and epithelial cells [15-24]. In particular, for these clinical applications, CHX-based solutions would be in direct contact with the bone and the connective tissues without the protective barrier of the intact epithelium, thus increasing the risk of cytotoxicity $[16,21]$. Regarding osteoblasts, $0.1 \% \mathrm{CHX}$ has been reported to rapidly induce morphological changes and cell damage in human osteoblasts already after an incubation time of one minute [25]. In John et al. [20], 0.2\% CHX was found to be cytotoxic for SaOS-2 cells. In a study investigating the effect of $\mathrm{CHX}$ on the same cell line, cell viability was reduced in dose- and time-dependent manners [26]. A dose-dependent $\mathrm{CHX}$ cytotoxicity was also observed in other in vitro studies $[15,17,23]$.

Furthermore, CHX-induced perioperative hypersensitivity has been extensively reported in the literature [27]. Although severe reactions are rarely observed in relation to mouthwashes, rinsing with an open flap might increase the risk of their occurrence.

To reduce the CHX-related side effects, shorter exposure time and/or lower concentration of $\mathrm{CHX}$ alone or in combination with additional compounds have been recommended. The combination CHX and cetylpyridinium chloride (CPC) has been demonstrated to be effective when used as an adjunct to oral hygiene for patients in supportive periodontal care [28-30], as well as in cases of peri-implant mucositis [31,32]. A $0.12 \% \mathrm{CHX}+$ $0.05 \%$ CPC solution was found to reduce bacterial load to a greater extent than mechanical debridement alone in respective peri-implantitis treatment [33] and exhibited similar clinical, radiographic and microbiological outcomes as compared to an alcohol containing $0.2 \%$ CHX [34]. Nevertheless, whether its additional use translates into enhanced clinical outcomes remains to be clarified.

In a recent study by our team [35], contrary to saline, two commercially available CHX-based mouthwashes (i.e., $0.05 \% \mathrm{CHX}+0.05 \% \mathrm{CPC}$ and $0.1 \% \mathrm{CHX}$ ) were found to be effective in the reduction of living bacteria in oral biofilms attached to micro-rough titanium surfaces. Following a $60 \mathrm{~s}$ exposure to the mouthwashes, no significant difference was found between the two groups in bacteria viability after 24 as well as $48 \mathrm{~h}$ of in situ plaque collection.

Taking into consideration the remarkable antibacterial properties exhibited by a $0.05 \%$ CHX $+0.05 \%$ CPC mouthwash and the well-documented cytotoxicity associated with antiseptics containing $\mathrm{CHX}$ at higher concertation, the relevant clinical question arose of whether it can be safely used as adjunctive in the surgical treatment of peri-implantitis.

Although numerous studies have investigated the effect of different concentrations of CHX on osteoblasts, to the best of our knowledge, the effects of a low-concentration CHX solution containing CPC on osteoblasts had not been explored yet. Therefore, the aim of this study was to evaluate in vitro the effects of three commercially available mouthwashes containing $\mathrm{CHX}$ at different dilutions, alone or in combination with CPC, on osteoblast-like cells by examining cell viability, cytotoxicity and apoptosis.

\section{Results}

Results on cell viability, cytotoxicity and apoptosis are reported below. No cell culture was lost due to microbial contamination. 


\subsection{Cell Viability}

The highest cell viability values were predictably detected in the control group $(\mathrm{NaCl})$ at all time points, as shown in Figure 1. Unexpectedly and not in accordance with the descriptive analysis illustrated in the boxplot, no significant difference was identified between $\mathrm{CHX} 0.2$ and $\mathrm{NaCl}$ groups at day $0(30 \mathrm{~s}, 60 \mathrm{~s}$ and $120 \mathrm{~s})$ as well as at day 3 (120 s) (Table 1). The $p$-values presented in Table 1 are Bonferroni-corrected. The uncorrected $p$-values were $<0.05$ in all these cases but one (30 s day $0: p=0.083$ ).

Table 1. Cell viability. A multiple Kruskal-Wallis test was performed to compare the groups at each time point (i.e., at day 0,3 and 6), and in the case of significance, a post hoc multiple comparison test with Bonferroni $p$-value adjustment was performed. The adjusted $p$-values from post hoc test are reported and labeled as follows: ${ }^{*} p<0.05,{ }^{* *} p<0.01,{ }^{* * *} p<0.001$.

\begin{tabular}{|c|c|c|c|c|c|}
\hline $\begin{array}{l}\text { Grouping } \\
\text { Variable }\end{array}$ & Comparator 1 & Comparator 2 & $\begin{array}{l}p \text {-Value } \\
\text { (Day 0) }\end{array}$ & $\begin{array}{l}p \text {-Value } \\
\text { (Day 3) }\end{array}$ & $\begin{array}{l}p \text {-Value } \\
\text { (Day 6) }\end{array}$ \\
\hline \multirow{9}{*}{ CHX 0.2} & $30 \mathrm{~s}$ & $60 \mathrm{~s}$ & 0.040 * & - & - \\
\hline & $30 \mathrm{~s}$ & $120 \mathrm{~s}$ & $0.005 * *$ & - & - \\
\hline & $60 s$ & $120 \mathrm{~s}$ & 1.000 & - & - \\
\hline & $30 \mathrm{~s}$ & $60 \mathrm{~s}$ & - & - & - \\
\hline & $30 \mathrm{~s}$ & $120 \mathrm{~s}$ & - & - & - \\
\hline & $60 \mathrm{~s}$ & $120 \mathrm{~s}$ & - & - & - \\
\hline & $30 \mathrm{~s}$ & $60 \mathrm{~s}$ & - & - & - \\
\hline & $30 \mathrm{~s}$ & $120 \mathrm{~s}$ & - & - & - \\
\hline & $60 s$ & $120 \mathrm{~s}$ & - & - & - \\
\hline \multirow{3}{*}{$\mathrm{NaCl}$} & $30 \mathrm{~s}$ & $60 \mathrm{~s}$ & - & - & $0.003^{* *}$ \\
\hline & $30 \mathrm{~s}$ & $120 \mathrm{~s}$ & - & - & 1.000 \\
\hline & $60 \mathrm{~s}$ & $120 \mathrm{~s}$ & - & - & $0.008^{* *}$ \\
\hline \multirow{18}{*}{$60 s$} & CHX 0.1 & CHX 0.2 & 0.033 * & 1.000 & 1.000 \\
\hline & CHX 0.1 & $\mathrm{CHX}+\mathrm{CPC}$ & 1.000 & 1.000 & 1.000 \\
\hline & CHX 0.1 & $\mathrm{NaCl}$ & $0.000^{* * *}$ & $0.006^{* *}$ & $0.007^{* *}$ \\
\hline & CHX 0.2 & $\mathrm{CHX}+\mathrm{CPC}$ & 0.141 & 1.000 & 1.000 \\
\hline & CHX 0.2 & $\mathrm{NaCl}$ & 0.499 & $0.007^{* *}$ & $0.004^{* *}$ \\
\hline & $\mathrm{CHX}+\mathrm{CPC}$ & $\mathrm{NaCl}$ & $0.000 * * *$ & $0.001 * *$ & 0.002 ** \\
\hline & CHX 0.1 & CHX 0.2 & 1.000 & 1.000 & 1.000 \\
\hline & CHX 0.1 & $\mathrm{CHX}+\mathrm{CPC}$ & 0.310 & 1.000 & 1.000 \\
\hline & CHX 0.1 & $\mathrm{NaCl}$ & 0.017 * & $0.001 * *$ & $0.007^{* *}$ \\
\hline & CHX 0.2 & $\mathrm{CHX}+\mathrm{CPC}$ & 0.054 & 1.000 & 1.000 \\
\hline & CHX 0.2 & $\mathrm{NaCl}$ & 0.123 & $0.008^{* *}$ & $0.000^{* * *}$ \\
\hline & $\mathrm{CHX}+\mathrm{CPC}$ & $\mathrm{NaCl}$ & $0.000^{* * *}$ & $0.009 * *$ & $0.016^{*}$ \\
\hline & CHX 0.1 & CHX 0.2 & 1.000 & 0.733 & 1.000 \\
\hline & CHX 0.1 & $\mathrm{CHX}+\mathrm{CPC}$ & 0.274 & 1.000 & 1.000 \\
\hline & CHX 0.1 & $\mathrm{NaCl}$ & 0.014 * & $0.000 * * *$ & $0.003^{* *}$ \\
\hline & CHX 0.2 & $\mathrm{CHX}+\mathrm{CPC}$ & 0.024 * & 1.000 & 1.000 \\
\hline & CHX 0.2 & $\mathrm{NaCl}$ & 0.185 & 0.050 & $0.004^{* *}$ \\
\hline & $\mathrm{CHX}+\mathrm{CPC}$ & $\mathrm{NaCl}$ & $0.000 * * *$ & $0.004^{* *}$ & $0.006^{* *}$ \\
\hline
\end{tabular}

Within all test groups, application time did not affect cell viability, except for CHX 0.1 at day 0 . Indeed, significant differences were observed between $30 \mathrm{~s}$ and the longer application times (i.e., $30 \mathrm{~s}$ vs. $60 \mathrm{~s} ; 30 \mathrm{~s}$ vs. $120 \mathrm{~s}$ ).

Only at day 0 , statistically significant differences were found between the test groups. In detail, CHX 0.2 presented higher values compared to CHX 0.1 and CHX + CPC after an application time of $30 \mathrm{~s}$ and $120 \mathrm{~s}$, respectively. 


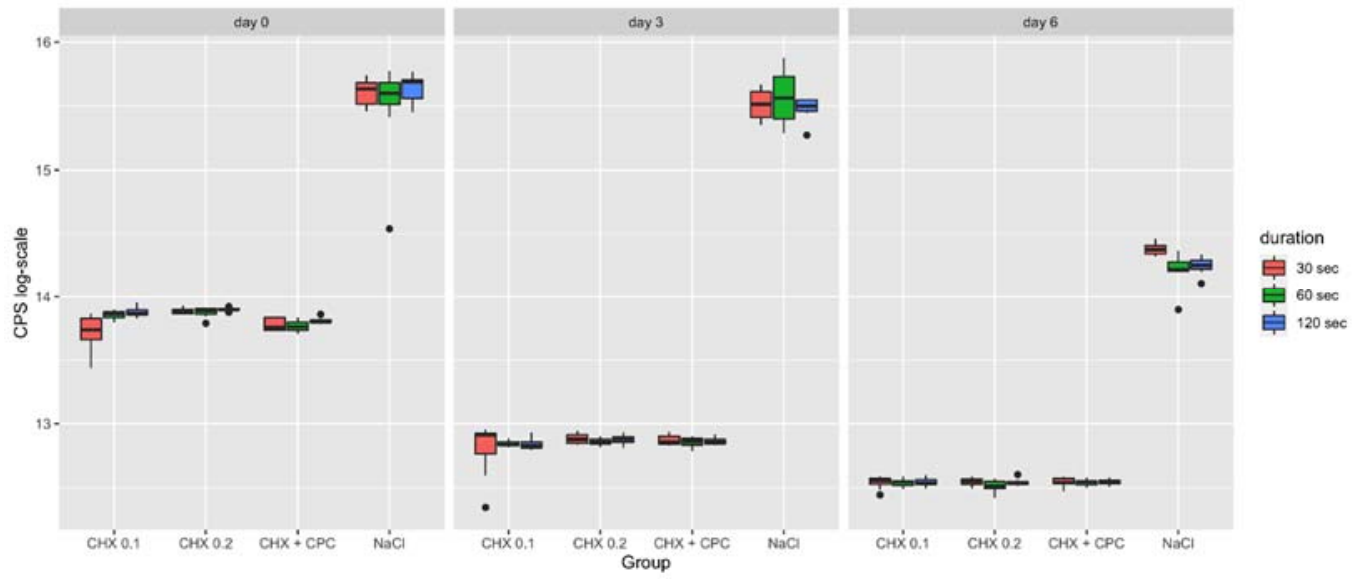

Figure 1. Boxplot representing the cell viability of SaOS-2 cells following the different treatment procedures (i.e., $\mathrm{CHX} 0.1$, $\mathrm{CHX} 0.2, \mathrm{CHX}+\mathrm{CPC}$ and $\mathrm{NaCl}$ for 30,60 and $120 \mathrm{~s}$ ) at day 0, 3 and 6. Data are expressed in counts per second (CPS).

\subsection{Cytotoxicity}

At day 0 , the highest cytotoxicity was detected in the CHX 0.2 group, which presented significantly higher values compared to CHX 0.1 (30 s), CHX + CPC ( $30 \mathrm{~s}, 60 \mathrm{~s}$ and $120 \mathrm{~s}$ ) and control ( $60 \mathrm{~s}$ and $120 \mathrm{~s}$ ). Lower cytotoxicity was exhibited by the CHX 0.1 as compared to $\mathrm{NaCl}$ after an application time of $30 \mathrm{~s}$, while the opposite was observed after $120 \mathrm{~s}$ $(p<0.05$ and $p<0.01$, respectively). For all the exposure times, no significant differences were found between CHX + CPC and CHX 0.1, as well as between CHX + CPC and the control. Moreover, at day 0 , the application time was not found to be determinant within the CHX 0.2 group. An increased cytotoxicity dependent on the application time was observed in both CHX 0.1 ( $60 \mathrm{~s}>30 \mathrm{~s}$ and $120 \mathrm{~s}>30 \mathrm{~s})$ and CHX + CPC (120 s > $30 \mathrm{~s})$. By contrast, within the $\mathrm{NaCl}$, results are inverted, with longer application times associated to a lower cytotoxicity compared to $30 \mathrm{~s}$ exposure.

As evidenced in the graph (Figure 2), at day 3 and day 6, a similar situation was observed, with the highest values recorded in the control group compared to the others. Contrary to day 0 , application time was found not to be relevant in the majority of cases. Likewise, for cell viability test, in contrast with what was reported in the boxplot, no significant difference was identified between $\mathrm{CHX} 0.2$ and $\mathrm{NaCl}$ at day 3 ( $30 \mathrm{~s}$ and $60 \mathrm{~s}$ ) and between $\mathrm{CHX} 0.1$ and $\mathrm{NaCl}$ at day $6(30 \mathrm{~s}$ ) (Table 2). The $p$-values presented in Table 2 are Bonferroni-corrected. The respected uncorrected $p$-values were $<0.05$ in all three cases.
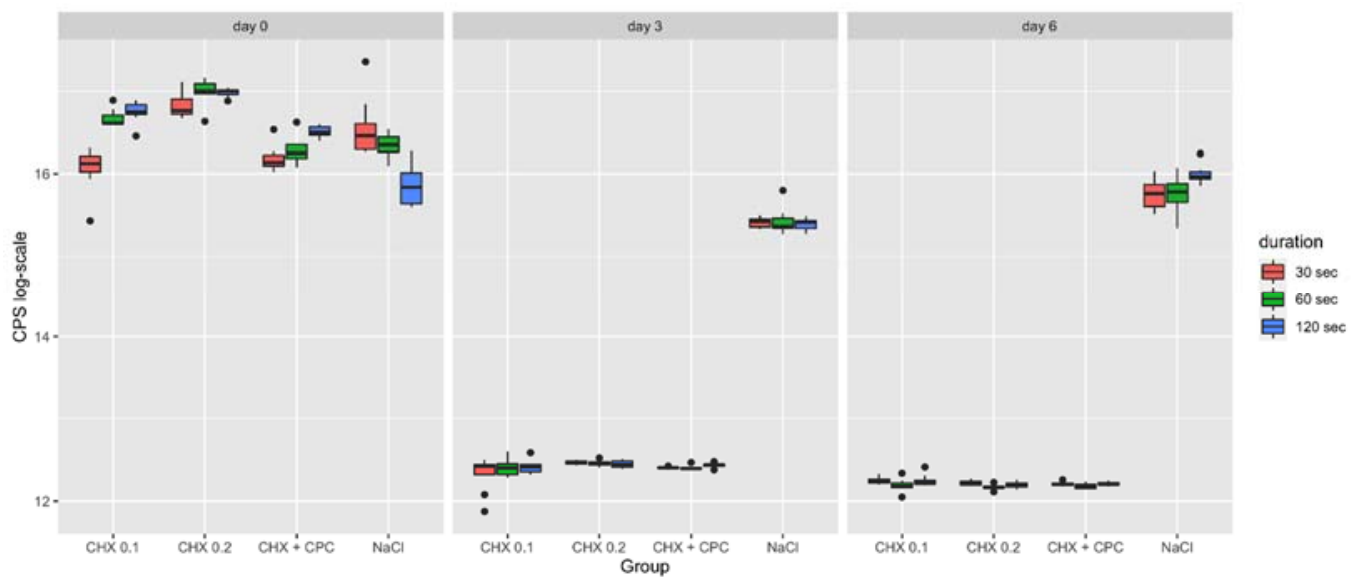

Figure 2. Boxplot representing the cytotoxicity on SaOS-2 cells following the different treatment procedures (i.e., CHX 0.1, $\mathrm{CHX} 0.2, \mathrm{CHX}+\mathrm{CPC}$ and $\mathrm{NaCl}$ for 30,60 and $120 \mathrm{~s}$ ) at day 0,3 and 6 . Data are expressed in counts per second (CPS). 
Table 2. Cytotoxicity. A multiple Kruskal-Wallis test was performed to compare the groups at each time point (i.e., at day 0, 3 and 6), and in the case of significance, a post hoc multiple comparison test with Bonferroni $p$-value adjustment was performed. The adjusted $p$-values from post hoc test are reported and labeled as follows: ${ }^{*} p<0.05,{ }^{* *} p<0.01,{ }^{* * *} p<0.001$.

\begin{tabular}{|c|c|c|c|c|c|}
\hline $\begin{array}{l}\text { Grouping } \\
\text { Variable }\end{array}$ & Comparator 1 & Comparator 2 & $\begin{array}{l}p \text {-Value } \\
\text { (Day 0) }\end{array}$ & $\begin{array}{l}p \text {-Value } \\
\text { (Day 3) }\end{array}$ & $\begin{array}{l}p \text {-Value } \\
\text { (Day 6) }\end{array}$ \\
\hline \multirow{9}{*}{ CHX 0.2} & $30 \mathrm{~s}$ & $60 \mathrm{~s}$ & $0.011^{*}$ & - & - \\
\hline & $30 \mathrm{~s}$ & $120 \mathrm{~s}$ & $0.000 * * *$ & - & - \\
\hline & $60 \mathrm{~s}$ & $120 \mathrm{~s}$ & 0.967 & - & - \\
\hline & $30 \mathrm{~s}$ & $60 \mathrm{~s}$ & - & - & 0.250 \\
\hline & $30 \mathrm{~s}$ & $120 \mathrm{~s}$ & - & - & 0.014 * \\
\hline & $60 \mathrm{~s}$ & $120 \mathrm{~s}$ & - & - & 0.819 \\
\hline & $30 \mathrm{~s}$ & $60 \mathrm{~s}$ & 0.916 & 0.231 & - \\
\hline & $30 \mathrm{~s}$ & $120 \mathrm{~s}$ & $0.004^{* *}$ & 0.030 * & - \\
\hline & $60 \mathrm{~s}$ & $120 \mathrm{~s}$ & 0.085 & 1.000 & - \\
\hline \multirow{3}{*}{$\mathrm{NaCl}$} & $30 \mathrm{~s}$ & $60 \mathrm{~s}$ & 0.014 * & - & 1.000 \\
\hline & $30 \mathrm{~s}$ & $120 \mathrm{~s}$ & $0.001^{* *}$ & - & $0.027 *$ \\
\hline & $60 \mathrm{~s}$ & $120 \mathrm{~s}$ & 1.000 & - & 0.071 \\
\hline \multirow{18}{*}{$60 \mathrm{~s}$} & CHX 0.1 & CHX 0.2 & $0.000^{* * *}$ & 0.695 & 1.000 \\
\hline & CHX 0.1 & $\mathrm{CHX}+\mathrm{CPC}$ & 1.000 & 1.000 & 0.733 \\
\hline & CHX 0.1 & $\mathrm{NaCl}$ & $0.043 *$ & 0.002 ** & 0.068 \\
\hline & CHX 0.2 & $\mathrm{CHX}+\mathrm{CPC}$ & 0.002 ** & 0.073 & 1.000 \\
\hline & CHX 0.2 & $\mathrm{NaCl}$ & 1.000 & 0.241 & $0.002 * *$ \\
\hline & $\mathrm{CHX}+\mathrm{CPC}$ & $\mathrm{NaCl}$ & 0.123 & $0.000 * * *$ & $0.000^{* * *}$ \\
\hline & CHX 0.1 & CHX 0.2 & 0.559 & 0.695 & 1.000 \\
\hline & CHX 0.1 & $\mathrm{CHX}+\mathrm{CPC}$ & 0.054 & 1.000 & 1.000 \\
\hline & CHX 0.1 & $\mathrm{NaCl}$ & 0.141 & $0.001^{* *}$ & $0.009^{* *}$ \\
\hline & CHX 0.2 & $\mathrm{CHX}+\mathrm{CPC}$ & $0.000^{* * *}$ & 0.472 & 1.000 \\
\hline & CHX 0.2 & $\mathrm{NaCl}$ & $0.000^{* * *}$ & 0.131 & $0.001^{* *}$ \\
\hline & $\mathrm{CHX}+\mathrm{CPC}$ & $\mathrm{NaCl}$ & 1.000 & $0.000^{* * *}$ & $0.006^{* *}$ \\
\hline & CHX 0.1 & CHX 0.2 & 0.420 & 1.000 & 1.000 \\
\hline & CHX 0.1 & $\mathrm{CHX}+\mathrm{CPC}$ & 0.947 & 1.000 & 1.000 \\
\hline & CHX 0.1 & $\mathrm{NaCl}$ & $0.006^{* *}$ & $0.001 * *$ & 0.033 * \\
\hline & CHX 0.2 & $\mathrm{CHX}+\mathrm{CPC}$ & $0.008^{* *}$ & 1.000 & 1.000 \\
\hline & CHX 0.2 & $\mathrm{NaCl}$ & $0.000 * * *$ & $0.017^{*}$ & 0.001 ** \\
\hline & $\mathrm{CHX}+\mathrm{CPC}$ & $\mathrm{NaCl}$ & 0.373 & $0.005^{* *}$ & $0.002^{* *}$ \\
\hline
\end{tabular}

\subsection{Apoptosis}

At all time points, the highest apoptotic levels were registered in the $\mathrm{NaCl}$ control group (Figure 3). As reported in Table 3, within each treatment and control group, at day 0 the application time was not found to significantly influence the apoptotic effect on SaOS-2 cells. At day 3, significant differences in apoptosis were observed between the $30 \mathrm{~s}$ and $120 \mathrm{~s}$ application times both in the $\mathrm{NaCl}$ and $\mathrm{CHX}+\mathrm{CPC}$. On the other hand, at day 6 , significant differences were registered within all groups but one (i.e., $\mathrm{CHX} 0.2$ ).

Unexpectedly and not in accordance with what was reported in the boxplot (Figure 3), there was no statistically significant difference between $\mathrm{NaCl}$ and $\mathrm{CHX}+\mathrm{CPC}$ groups at day $3(120 \mathrm{~s})$ and at day $6(30 \mathrm{~s})$. The $p$-values presented in Table 3 are Bonferroni-corrected. The uncorrected $p$-values were $<0.05$ in both cases. 


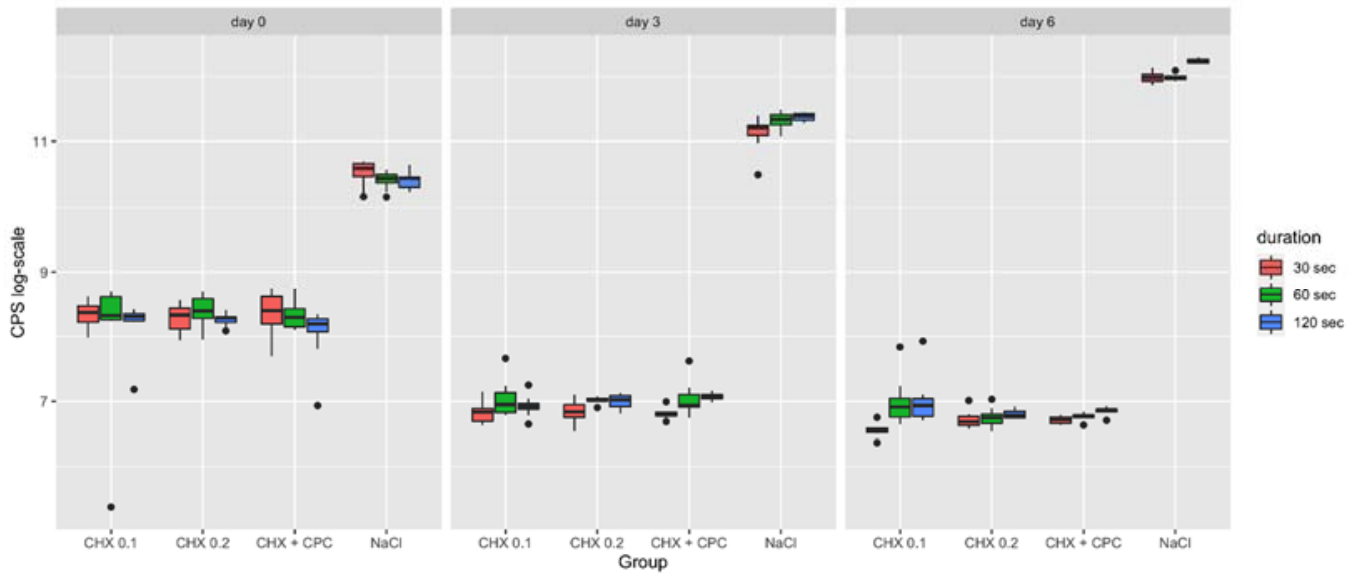

Figure 3. Boxplot representing the apoptosis of SaOS-2 cells following the different treatment procedures (i.e., $\mathrm{CHX} 0.1$, $\mathrm{CHX} 0.2, \mathrm{CHX}+\mathrm{CPC}$ and $\mathrm{NaCl}$ for 30,60 and $120 \mathrm{~s}$ ) at day 0, 3 and 6. Data are expressed in counts per second (CPS).

Table 3. Apoptosis. A multiple Kruskal-Wallis test was performed to compare the groups at each time point (i.e., at day 0, 3 and 6), and in the case of significance, a post hoc multiple comparison test with Bonferroni $p$-value adjustment was performed. The adjusted $p$-values from post hoc test are reported and labeled as follows: ${ }^{*} p<0.05,{ }^{* *} p<0.01,{ }^{* * *} p<0.001$.

\begin{tabular}{|c|c|c|c|c|c|}
\hline $\begin{array}{l}\text { Grouping } \\
\text { Variable }\end{array}$ & Comparator 1 & Comparator 2 & $\begin{array}{c}p \text {-Value } \\
\text { (Day 0) }\end{array}$ & $\begin{array}{c}p \text {-Value } \\
\text { (Day 3) }\end{array}$ & $\begin{array}{c}p \text {-Value } \\
\text { (Day 6) }\end{array}$ \\
\hline \multirow{9}{*}{ CHX 0.2} & $30 \mathrm{~s}$ & $60 \mathrm{~s}$ & - & - & $0.005^{* *}$ \\
\hline & $30 \mathrm{~s}$ & $120 \mathrm{~s}$ & - & - & $0.003^{* *}$ \\
\hline & $60 \mathrm{~s}$ & $120 \mathrm{~s}$ & - & - & 1.000 \\
\hline & $30 \mathrm{~s}$ & $60 \mathrm{~s}$ & - & - & - \\
\hline & $30 \mathrm{~s}$ & $120 \mathrm{~s}$ & - & - & - \\
\hline & $60 \mathrm{~s}$ & $120 \mathrm{~s}$ & - & - & - \\
\hline & $30 \mathrm{~s}$ & $60 \mathrm{~s}$ & - & 0.078 & 0.915 \\
\hline & $30 \mathrm{~s}$ & $120 \mathrm{~s}$ & - & $0.002^{* *}$ & $0.003^{* *}$ \\
\hline & $60 \mathrm{~s}$ & $120 \mathrm{~s}$ & - & 0.730 & 0.074 \\
\hline \multirow{3}{*}{$\mathrm{NaCl}$} & $30 \mathrm{~s}$ & $60 \mathrm{~s}$ & - & 0.121 & 1.000 \\
\hline & $30 \mathrm{~s}$ & $120 \mathrm{~s}$ & - & 0.014 * & $0.004^{* *}$ \\
\hline & $60 \mathrm{~s}$ & $120 \mathrm{~s}$ & - & 1.000 & $0.009^{* *}$ \\
\hline \multirow{18}{*}{$60 \mathrm{~s}$} & CHX 0.1 & CHX 0.2 & 1.000 & 1.000 & 0.320 \\
\hline & CHX 0.1 & $\mathrm{CHX}+\mathrm{CPC}$ & 1.000 & 1.000 & 0.173 \\
\hline & CHX 0.1 & $\mathrm{NaCl}$ & $0.004^{* *}$ & $0.004^{* *}$ & $0.000^{* * *}$ \\
\hline & CHX 0.2 & $\mathrm{CHX}+\mathrm{CPC}$ & 1.000 & 1.000 & 1.000 \\
\hline & CHX 0.2 & $\mathrm{NaCl}$ & $0.001^{* *}$ & $0.006^{* *}$ & $0.026^{*}$ \\
\hline & $\mathrm{CHX}+\mathrm{CPC}$ & $\mathrm{NaCl}$ & 0.010 * & $0.002 * *$ & 0.056 \\
\hline & CHX 0.1 & CHX 0.2 & 1.000 & 1.000 & 1.000 \\
\hline & CHX 0.1 & $\mathrm{CHX}+\mathrm{CPC}$ & 1.000 & 1.000 & 1.000 \\
\hline & CHX 0.1 & $\mathrm{NaCl}$ & $0.006^{* *}$ & $0.002 * *$ & 0.048 * \\
\hline & CHX 0.2 & $\mathrm{CHX}+\mathrm{CPC}$ & 1.000 & 1.000 & 1.000 \\
\hline & CHX 0.2 & $\mathrm{NaCl}$ & $0.006^{* *}$ & $0.011 *$ & $0.001^{* *}$ \\
\hline & $\mathrm{CHX}+\mathrm{CPC}$ & $\mathrm{NaCl}$ & $0.002^{* *}$ & $0.002 * *$ & $0.002^{* *}$ \\
\hline & CHX 0.1 & CHX 0.2 & 1.000 & 1.000 & 0.878 \\
\hline & CHX 0.1 & $\mathrm{CHX}+\mathrm{CPC}$ & 1.000 & 0.472 & 1.000 \\
\hline & CHX 0.1 & $\mathrm{NaCl}$ & 0.020 * & $0.000^{* * *}$ & $0.036^{*}$ \\
\hline & CHX 0.2 & $\mathrm{CHX}+\mathrm{CPC}$ & 1.000 & 1.000 & 1.000 \\
\hline & CHX 0.2 & $\mathrm{NaCl}$ & $0.006^{* *}$ & $0.004^{* *}$ & $0.000^{* * *}$ \\
\hline & $\mathrm{CHX}+\mathrm{CPC}$ & $\mathrm{NaCl}$ & $0.000^{* * *}$ & 0.068 & $0.006^{* *}$ \\
\hline
\end{tabular}

\section{Discussion}

The purpose of this study was to determine the impact of three commercially available mouthwashes containing chlorhexidine ( $\mathrm{CHX}$ ) at different concentrations, alone or in combination with cetylpyridinium chloride (CPC), on osteoblast-like cells (SaOS-2) cultured 
for $2 \mathrm{~h}, 3$ days and 6 days after different exposure times to the mouthwashes tested in this study (i.e., $30 \mathrm{~s}, 60 \mathrm{~s}$ and $120 \mathrm{~s}$ ).

Among the tested mouthwashes, the highest cell viability values were predictably recorded in the $\mathrm{NaCl}$ (control) group at all three time points, and for all application times. Except for day 0, in which CHX 0.2 showed higher values than CHX 0.1 at $30 \mathrm{~s}$ application time as well as higher values than CHX + CPC at an application time of $120 \mathrm{~s}$, cell viability was comparable among the tested mouthwashes. The application time did not reveal any effect on cell viability within the test groups except for CHX 0.1 at day 0 .

Besides cell viability, the triplex assay utilized in the present study allowed for exploring the SaOS-2 death mechanism induced by the different treatment procedures. Contrary to apoptosis, which is characterized by cell membrane integrity, its disruption and the subsequent release of the cytoplasmic contents into the surrounding tissue occur in case of necrosis [36,37].

Hence, in virtue of the different morphological features of these two cellular death mechanisms, it was possible to assess the cytotoxicity by means of a fluorogenic proteolytic biomarker that is released from cells that have lost their membrane integrity. The exposure to CHX 0.2 resulted in significantly higher cytotoxicity levels at day 0 compared to CHX 0.1 (30 s), $\mathrm{CHX}+\mathrm{CPC}$ (30 s, $60 \mathrm{~s}$ and $120 \mathrm{~s}$ ) and $\mathrm{NaCl}$ (60 s and $120 \mathrm{~s}$ ). No significant differences were found between $\mathrm{CHX}+\mathrm{CPC}$ and both $\mathrm{CHX} 0.1$ and $\mathrm{NaCl}$ for all the application times. Interestingly, $\mathrm{CHX}+\mathrm{CPC}$ as well as $\mathrm{CHX} 0.1$ exhibited a time-dependent cytotoxicity on SaOS-2, whereas an inverse correlation between application time and cytotoxic effect was observed in the $\mathrm{NaCl}$ group at day 0 . This finding can hardly be explained, as longer rinsing procedures were expected to be associated with higher cellular stress. Nevertheless, as emerged from cell viability assay, well recovery of the cells was evidenced in the control group at day 3 and 6 . By contrast, the low cytotoxicity levels in all the test groups at these time points might be attributed to the early death of a great amount of SaOS-2 once in contact with CHX-based agents.

Caspase activation is considered a hallmark of programmed death, or apoptosis [38]. In the current study, caspase- $3 / 7$ substrates were utilized for the detection of the activity of these two effector caspases. In a previous study of this group [20], utilizing the same assessment method and cell line (i.e., SaOS-2) to test the in vitro properties of antimicrobial agents, a different control was adopted, i.e., pure water instead of $\mathrm{NaCl}$. Regardless of the type of control, in both studies, higher apoptosis values were detected in the presence of the control compared to CHX-based ones. The low apoptotic levels registered among the test groups might be attributed to the dominant cytotoxic effect of the mouthwashes, while the results detected in the control group might be due to common environmental stress, especially after longer culture time, related to cell confluence, increased amount of waste products and reduced nutrition medium [39].

A fundamental condition for the successful treatment of peri-implantitis is the reosseointegration of the implants. One of the determinant factors influencing this process, i.e., the re-osseointegration, consists in the effective decontamination of dental implants. To this aim, several approaches have been proposed, with no proven long-term clinical advantage of one method over the others [5,40]. Chemical agents can be used intraoperatively, alone or in combination with other methods, to eliminate bacterial biofilm adhering to the exposed implant surfaces. Indeed, peri-procedural rinsing with $\mathrm{CHX}$ has also been recommended for implant surgery in order to reduce the bacterial load [41]. Furthermore, rinsing with CHX after periodontal and implant surgery has been correlated with a significant reduction in plaque and bleeding as compared to placebo [42]. Besides their antimicrobial properties, these products should not exert a detrimental effect on the surrounding tissues, and eventual residues should not compromise the cellular response to the decontaminated surfaces [43]. Re-osteointegration largely depends on the initial cell response at the cellimplant interface. The main cells responsible for new bone apposition are osteoblasts and their precursors; therefore, assessing the effect of different mouthwashes on these cells is particularly relevant for the proposed clinical application. 
Prior in vitro research has demonstrated the cytotoxicity of $\mathrm{CHX}$ on both osteoblastic and osteoblastic-like (e.g., SaOS-2) cell lines. In a previous paper by our group using a similar study design [20], at day 0, CHX 0.2 exhibited the highest cytotoxicity on SaOS2 , especially after $120 \mathrm{~s}$ of exposure, with significantly higher values compared to the taurolidine 2\% and the pure water group. In Giannelli et al. [26], exposure to CHX induced a decrease in SaOS-2 cell viability in a dose- and time-dependent manner, while in the present study, the differences between the groups (different $\mathrm{CHX}$ concentration/application time) were not pronounced. Similar to our investigation, CHX-based mouthwashes were able to induce both apoptosis and necrosis. The treatment with $0.2 \% \mathrm{CHX}$ also induced a drastic reduction of viability of both SaOS-2 and bone marrow mesenchymal stromal cells seeded onto titanium disks as compared to untreated cells [44]. Interestingly, CHX-induced cell damage resulted in being attenuated by rinsing with PBS, and even more if followed by air drying. In Vörös et al., $0.1 \%$ CHX was found to cause cell damage on human osteoblasts already after an incubation time of one minute [25]. The viability of murine osteoblast precursor cells significantly decreased when exposed to $0.12 \% \mathrm{CHX}$ as compared to the control, irrespectively of the application time ranging from $30 \mathrm{~s}$ to $4.5 \mathrm{~min}$ [45].

The cytotoxic profile of $\mathrm{CHX}$ was also corroborated at lower concentrations. Osteoblast survival rate $48 \mathrm{~h}$ after an exposure to $\mathrm{CHX}(0.002 \%)$ was significantly reduced as compared to the control for all the exposure times (i.e., $1 \mathrm{~m}, 2 \mathrm{~m}$ and $3 \mathrm{~m}$ ) (Liu et al., 2018). The low viability levels registered in this last work could have been ascribed to the relatively short culture time, masking the regenerative capacity of the cells over time. Therefore, in a recent study investigating the effect of different antiseptic solutions, a longer observation time was selected as in our paper [46]. The cytotoxic effect of CHX was confirmed also at a low concentration $(0.05 \%)$, with human osteoblast cells failing to recover over the course of 5 days.

To the best of our knowledge, no other paper has previously investigated the effect of a $0.05 \% \mathrm{CHX}+0.05 \% \mathrm{CPC}$ solution on osteoblast-like cells in vitro. However, the current study presents some limitations. Firstly, it was confined to a laboratory setting and the obtained results may not correspond to the oral environment, as a monolayer cell culture model cannot fully represent the bone tissue exposure to the antiseptic agents. Osteoblastlike cells were here directly exposed to the mouthwashes, while in vivo they reside within the mineralized bone tissue, which may reduce the permeability and the adsorption of the chemicals. Many aspects cannot be investigated in vitro, including the dilution of the mouthwashes in the fluids present in the oral cavity, the immunological response of the organism, as well as the tissue alterations resulting from the pathology itself [25]. In the present work, a two-dimensional (2D) system was chosen due to the high reproducibility of the experimental results and the ease of culture maintenance. Nevertheless, the morphology as well as the functions of cells grown as a monolayer attached to a glass or plastic surface resulted in being altered compared to those in the natural environment $[47,48]$. Despite the higher costs and technical difficulties, three-dimensional (3D) cell culture models have gained increasing interest owing to their closer resemblance to the in vivo microenvironment $[47,49]$. Furthermore, bone repair is a complex process which involves the well-orchestrated interactions between different cells and signals [50]. Microvascular circulation is considered a key component during tissue repair, and the lack of angiogenesis or its inhibition has been reported to hamper bone healing [51]. Newly formed vessels not only supply nutrients and oxygen to meet the local metabolic demands, but also produce inflammatory and injury-induced angiocrine signals, which contribute to guiding bone regeneration [52]. Therefore, 3D co-cultures of osteoblasts and endothelial cells or concurrent multi-lineage differentiation of stem cells might be considered for future studies, prior to in vivo preclinical investigations or human clinical trials.

It is worth mentioning that human tissues usually present a higher tolerance for antiseptic agents compared to monolayer tissue cultures [24]. Indeed, higher regenerative potential is observed in vivo, where the recruitment of osteoprogenitors, hematopoietic stem cells and immune cells plays a fundamental role in tissue regeneration and remodel- 
ing [50]. Moreover, the fast growing of cells on a plastic support may further contribute to cell damage, as testified by the high cytotoxicity and apoptotic values reported in the control group at day 3 and 6 . When resective surgical treatment of peri-implantitis was combined with surface decontamination with a $0.12 \% \mathrm{CHX}+0.05 \% \mathrm{CPC}$ solution, a reduction of the anaerobic bacterial load was observed as compared to a placebo solution [33]. The significant reduction in bacterial load did not translate into an overall clinical or radiographical benefit. However, no detrimental effect was associated with the antiseptic agent. As a consequence, a CHX + CPC solution containing an even lower concentration of CHX could represent a safe antiseptic for this specific application.

Finally, implant surface characteristics have been demonstrated to affect cell response. Therefore, it would be interesting to investigate the effect of the mouthwashes on cells seeded onto different implant surfaces. Pre-treatment of the implant surfaces, simulating commonly applied clinical procedures such as implantoplasty, and different rinsing times with PBS or water after mouthwash application might also be determinant.

All of the mouthwashes tested here caused irreversible SaOS-2 cell damage, as confirmed by the low viability values and the respective low cytotoxicity and apoptotic levels registered at day 3 and 6 . The main differences among the tested treatment procedures were observed at day 0 , when overall the CHX 0.2 solution was found to exert a higher cytotoxic effect as comparted to the other mouthwashes. While a time-related effect on cell recovery and death was not noticed in the majority of the cases in all the experiments, at day 0 shorter application times were associated to lower cell cytotoxicity in both the $\mathrm{CHX}$ 0.1 and CHX + CPC group. It can be deduced that both these products could be considered for intraoperative usage, especially for a short rinsing time, while long application time and the exposure to CHX at the standard concentration of $0.2 \%$ should be avoided. How the present findings could be translated into a clinical situation remains to be clarified.

\section{Materials and Methods}

\subsection{Cell Culture}

Osteoblast-like cells (SaOS-2 cells) were seeded on sterile 96-well binding cell-culture plates (Costar 9102, Kennebunk, ME, USA). Following the protocol described in John et al. (John et al., 2014), 10,000 SaOS-2 cells (Acc 243, fourth passage, German Collection of Microorganisms and Cell Cultures $\mathrm{GmbH}$, Braunschweig, Germany) were cultured for 3 days in $200 \mu \mathrm{L}$ of high-glucose Dulbecco's Modified Eagle Medium (DMEM, SigmaAldrich, Merck Group, St. Louis, MO, USA) supplemented with $10 \%$ fetal bovine serum (Sigma-Aldrich) and $1 \%$ penicillin/streptomycin (Gibco Invitrogen, Darmstadt, Germany) at a temperature of $37^{\circ} \mathrm{C}, 95 \%$ of humidity and $5 \% \mathrm{CO}_{2}$.

\subsection{Treatment Procedure}

After 3-day cell culture, a total of 288 wells were randomly assigned to the following treatment groups: $0.05 \% \mathrm{CPC}+0.05 \% \mathrm{CHX}$ (PERIO-AID ${ }^{\circledR}$ Active Control, Dentaid ${ }^{\circledR} \mathrm{GmbH}$, Barcelona, Spain) (CPC + CHX), 0.1\% CHX (Chlorhexamed ${ }^{\circledR}$ Fluid 0.1\%, GlaxoSmithKline Consumer Healthcare GmbH \& Co. KG, Bühl, Germany), 0.2\% CHX (Chlorhexamed ${ }^{\circledR}$ Forte $0.2 \%$, GlaxoSmithKline Consumer Healthcare GmbH \& Co. KG), and sterile saline $(\mathrm{NaCl})$ as control. In the attempt to replicate in vitro the situation of a mouthwash, nutrition medium was removed before the treatment and cells were gently rinsed with phosphate buffered saline (PBS, Sigma-Aldrich). Three treatment times (i.e., 30, 60 and 120 s) were tested in each of the four groups.

Test and control mouthwashes were removed, the wells were gently rinsed with PBS and $200 \mu \mathrm{L}$ of high-glucose DMEM was applied per well. Two hours (day 0), 3 days and 6 days after the treatment procedure with the mouthwashes, cell viability, cytotoxicity and apoptosis were assessed. In the 6-day groups, the nutrition medium was changed at day 3 . Before performing the tests, the nutrition medium was removed and the wells were gently rinsed with PBS.

For each application time and assessment time point, 8 wells per product were examined. 


\subsection{Cell Viability, Cytotoxicity and Apoptosis}

The effect of different treatment procedures on cell viability, cytotoxicity and apoptosis was determined by means of a triplex assay (ApoTox-Glo ${ }^{\mathrm{TM}}$ Triplex Assay, Promega, Mannhein, Germany) following manufacturer's instructions.

Firstly, cell viability and cytotoxicity were assessed simultaneously by fluorometry, measuring two protease activities. A viability/cytotoxicity reagent, containing both glycyphenylalanyl-aminofluorocoumarin (GF-AFC) and bis-alanylalanyl-phenylalnylrhodamine 100 (AAF-R110), was utilized. GF-AFC is a cell-permeant peptide which enters intact living cells where it is converted into amino fluorocoumarin (AFC), generating a fluorescent signal proportional to the amount of living cells. AAF-R110 is a cell-impermeant peptide, which is converted by dead-cell protease in rhodamine 110 (R100), when the protease is released in the culture medium due to the loss of cell membrane integrity. The metabolic products can be detected simultaneously, owing to the different mission spectra (AFC in green and R110 in red). Thereafter, for apoptosis, caspase-3/7 activity was measured by adding a luminogenic caspase- $3 / 7$ substrate, which can be evaluated via the production of a luminescent signal proportional to the amount of caspase activity present.

All signal measurements were performed using a luminometer/fluorometer (Victor 2030, PerkinElmer, Rodgau, Germany). Results were expressed in counts per second (CPS).

\subsection{Statistical Analysis}

Statistical evaluation was performed using the software R [53]. For each time point, application time and mouthwash, boxplots were created for descriptive purposes. The Kruskal-Wallis test, post hoc multiple comparison test and Bonferroni method for $p$-value adjustment were used to assess statistical differences in cell viability, cytotoxicity and apoptosis among the three treatment groups per time point, and adjusted $p$-values were reported. The results were considered significant at $p<0.05$.

\section{Conclusions}

Further studies are needed to determine the impact of the different products and rinsing times on wound healing when they are used intraoperatively, in direct contact with the bone. Besides the safety of the rinsing procedure, their efficacy in terms of bacterial load reduction, improved bone healing and decreased peri-implantitis recurrences should also be investigated. It would also be important to evaluate the clinical effects of peri-incisional rinsing and postoperative dressings containing CHX-based solutions.

Future research could also be tailored to the investigation of different rinsing protocols in similar contexts, such as extraction socket rinsing or other surgical procedures in which a full thickness mucoperiosteal flap is raised, exposing the bone to the oral cavity.

Author Contributions: Conceptualization, K.B. and G.J.; formal analysis, G.B. and K.B.; investigation, L.S. and G.J.; data curation, K.B. and G.J.; writing—original draft preparation G.B. and K.B.; writing-review and editing, G.B., K.B., D.D., J.B. and G.J.; supervision, D.D., J.B. and G.J.; project administration, K.B. and G.J.; funding acquisition, K.B. All authors have read and agreed to the published version of the manuscript.

Funding: The PERIO-AID ${ }^{\circledR}$ Active Control mouthwashes were provided free of cost by Dentaid ${ }^{\circledR}$ $\mathrm{GmbH}$ (Barcelona, Spain).

Institutional Review Board Statement: Not applicable.

Informed Consent Statement: Not applicable.

Data Availability Statement: Data will be provided upon reasonable request.

Acknowledgments: The authors would like to thank Brigitte Hartig and Tina Hagena for their skillful technical assistance. The PERIO-AID ${ }^{\circledR}$ Active Control mouthwashes were provided free of cost by Dentaid ${ }^{\circledR} \mathrm{GmbH}$ (Barcelona, Spain).

Conflicts of Interest: The authors declare no conflict of interest. 


\section{References}

1. Schwarz, F.; Derks, J.; Monje, A.; Wang, H.L. Peri-implantitis. J. Periodontol. 2018, 89 (Suppl. 1), S267-s290. [CrossRef] [PubMed]

2. Derks, J.; Schaller, D.; Håkansson, J.; Wennström, J.L.; Tomasi, C.; Berglundh, T. Peri-implantitis-onset and pattern of progression. J. Clin. Periodontol. 2016, 43, 383-388. [CrossRef]

3. Klinge, B.; Klinge, A.; Bertl, K.; Stavropoulos, A. Peri-implant diseases. Eur. J. Oral Sci. 2018, 126 (Suppl. 1), 88-94. [CrossRef]

4. Schwarz, F.; Becker, K.; Sager, M. Efficacy of professionally administered plaque removal with or without adjunctive measures for the treatment of peri-implant mucositis. A systematic review and meta-analysis. J. Clin. Periodontol. 2015, 42 (Suppl. 16), S202-S213. [CrossRef]

5. Khoury, F.; Keeve, P.L.; Ramanauskaite, A.; Schwarz, F.; Koo, K.T.; Sculean, A.; Romanos, G. Surgical treatment of peri-implantitisConsensus report of working group 4. Int. Dent. J. 2019, 69 (Suppl. 2), 18-22. [CrossRef]

6. Koo, K.T.; Khoury, F.; Keeve, P.L.; Schwarz, F.; Ramanauskaite, A.; Sculean, A.; Romanos, G. Implant Surface Decontamination by Surgical Treatment of Periimplantitis: A Literature Review. Implant Dent. 2019, 28, 173-176. [CrossRef]

7. Renvert, S.; Polyzois, I.; Claffey, N. Surgical therapy for the control of peri-implantitis. Clin. Oral Implant. Res. 2012, 23 (Suppl. 6), 84-94. [CrossRef]

8. Schwarz, F.; Schmucker, A.; Becker, J. Efficacy of alternative or adjunctive measures to conventional treatment of peri-implant mucositis and peri-implantitis: A systematic review and meta-analysis. Int. J. Implant Dent. 2015, 1, 22. [CrossRef] [PubMed]

9. Daubert, D.M.; Weinstein, B.F. Biofilm as a risk factor in implant treatment. Periodontology 2000 2019, 81, 29-40. [CrossRef]

10. Carcuac, O.; Derks, J.; Abrahamsson, I.; Wennström, J.L.; Petzold, M.; Berglundh, T. Surgical treatment of peri-implantitis: 3-year results from a randomized controlled clinical trial. J. Clin. Periodontol. 2017, 44, 1294-1303. [CrossRef]

11. Carcuac, O.; Derks, J.; Charalampakis, G.; Abrahamsson, I.; Wennström, J.; Berglundh, T. Adjunctive Systemic and Local Antimicrobial Therapy in the Surgical Treatment of Peri-implantitis: A Randomized Controlled Clinical Trial. J. Dent. Res. 2016, 95, 50-57. [CrossRef]

12. Carcuac, O.; Abrahamsson, I.; Charalampakis, G.; Berglundh, T. The effect of the local use of chlorhexidine in surgical treatment of experimental peri-implantitis in dogs. J. Clin. Periodontol. 2015, 42, 196-203. [CrossRef]

13. Zhou, J.; Hu, B.; Liu, Y.; Yang, Z.; Song, J. The efficacy of intra-alveolar $0.2 \%$ chlorhexidine gel on alveolar osteitis: A meta-analysis. Oral. Dis. 2017, 23, 598-608. [CrossRef]

14. Paunio, K.U.; Knuttila, M.; Mielitynen, H. The effect of chlorhexidine gluconate on the formation of experimental granulation tissue. J. Periodontol. 1978, 49, 92-95. [CrossRef]

15. Cabral, C.T.; Fernandes, M.H. In vitro comparison of chlorhexidine and povidone-iodine on the long-term proliferation and functional activity of human alveolar bone cells. Clin. Oral. Investig. 2007, 11, 155-164. [CrossRef] [PubMed]

16. Faria, G.; Cardoso, C.R.; Larson, R.E.; Silva, J.S.; Rossi, M.A. Chlorhexidine-induced apoptosis or necrosis in L929 fibroblasts: A role for endoplasmic reticulum stress. Toxicol. Appl. Pharmacol. 2009, 234, 256-265. [CrossRef]

17. Verdugo, F.; Sáez-Rosón, A.; Uribarri, A.; Martínez-Conde, R.; Cabezas-Olcoz, J.; Moragues, M.D.; Pontón, J. Bone microbial decontamination agents in osseous grafting: An in vitro study with fresh human explants. J. Periodontol. 2011, 82, 863-871. [CrossRef]

18. Schmidt, J.; Zyba, V.; Jung, K.; Rinke, S.; Haak, R.; Mausberg, R.F.; Ziebolz, D. Cytotoxic effects of octenidine mouth rinse on human fibroblasts and epithelial cells-An in vitro study. Drug Chem. Toxicol. 2016, 39, 322-330. [CrossRef] [PubMed]

19. Schmidt, J.; Zyba, V.; Jung, K.; Rinke, S.; Haak, R.; Mausberg, R.F.; Ziebolz, D. Effects of octenidine mouth rinse on apoptosis and necrosis of human fibroblasts and epithelial cells-an in vitro study. Drug Chem. Toxicol. 2018, 41, 182-187. [CrossRef]

20. John, G.; Becker, J.; Schwarz, F. Effects of taurolidine and chlorhexidine on SaOS-2 cells and human gingival fibroblasts grown on implant surfaces. Int. J. Oral Maxillofac. Implant. 2014, 29, 728-734. [CrossRef]

21. Müller, H.D.; Eick, S.; Moritz, A.; Lussi, A.; Gruber, R. Cytotoxicity and Antimicrobial Activity of Oral Rinses In Vitro. BioMed Res. Int. 2017, 2017, 4019723. [CrossRef]

22. Coelho, A.S.; Laranjo, M.; Gonçalves, A.C.; Paula, A.; Paulo, S.; Abrantes, A.M.; Caramelo, F.; Ferreira, M.M.; Silva, M.J.; Carrilho, E.; et al. Cytotoxic effects of a chlorhexidine mouthwash and of an enzymatic mouthwash on human gingival fibroblasts. Odontology 2020, 108, 260-270. [CrossRef]

23. Lee, T.H.; Hu, C.C.; Lee, S.S.; Chou, M.Y.; Chang, Y.C. Cytotoxicity of chlorhexidine on human osteoblastic cells is related to intracellular glutathione levels. Int. Endod. J. 2010, 43, 430-435. [CrossRef]

24. Liu, J.X.; Werner, J.; Kirsch, T.; Zuckerman, J.D.; Virk, M.S. Cytotoxicity evaluation of chlorhexidine gluconate on human fibroblasts, myoblasts, and osteoblasts. J. Bone Jt. Infect. 2018, 3, 165-172. [CrossRef]

25. Vörös, P.; Dobrindt, O.; Perka, C.; Windisch, C.; Matziolis, G.; Röhner, E. Human osteoblast damage after antiseptic treatment. Int Orthop. 2014, 38, 177-182. [CrossRef] [PubMed]

26. Giannelli, M.; Chellini, F.; Margheri, M.; Tonelli, P.; Tani, A. Effect of chlorhexidine digluconate on different cell types: A molecular and ultrastructural investigation. Toxicol. Vitr. Int. J. Publ. Assoc. BIBRA 2008, 22, 308-317. [CrossRef]

27. Rose, M.A.; Garcez, T.; Savic, S.; Garvey, L.H. Chlorhexidine allergy in the perioperative setting: A narrative review. Br. J. Anaesth. 2019, 123, e95-e103. [CrossRef]

28. Escribano, M.; Herrera, D.; Morante, S.; Teughels, W.; Quirynen, M.; Sanz, M. Efficacy of a low-concentration chlorhexidine mouth rinse in non-compliant periodontitis patients attending a supportive periodontal care programme: A randomized clinical trial. J. Clin. Periodontol. 2010, 37, 266-275. [CrossRef] 
29. Santos, S.; Herrera, D.; López, E.; O’Connor, A.; González, I.; Sanz, M. A randomized clinical trial on the short-term clinical and microbiological effects of the adjunctive use of a $0.05 \%$ chlorhexidine mouth rinse for patients in supportive periodontal care. J. Clin. Periodontol. 2004, 31, 45-51. [CrossRef]

30. Quirynen, M.; Soers, C.; Desnyder, M.; Dekeyser, C.; Pauwels, M.; van Steenberghe, D. A 0.05\% cetyl pyridinium chloride/0.05\% chlorhexidine mouth rinse during maintenance phase after initial periodontal therapy. J. Clin. Periodontol. 2005, 32, 390-400. [CrossRef]

31. Bollain, J.; Pulcini, A.; Sanz-Sánchez, I.; Figuero, E.; Alonso, B.; Sanz, M.; Herrera, D. Efficacy of a 0.03\% chlorhexidine and 0.05\% cetylpyridinium chloride mouth rinse in reducing inflammation around the teeth and implants: A randomized clinical trial. Clin. Oral Investig. 2021, 25, 1729-1741. [CrossRef] [PubMed]

32. Pulcini, A.; Bollaín, J.; Sanz-Sánchez, I.; Figuero, E.; Alonso, B.; Sanz, M.; Herrera, D. Clinical effects of the adjunctive use of a $0.03 \%$ chlorhexidine and $0.05 \%$ cetylpyridinium chloride mouth rinse in the management of peri-implant diseases: A randomized clinical trial. J. Clin. Periodontol. 2019, 46, 342-353. [CrossRef] [PubMed]

33. de Waal, Y.C.; Raghoebar, G.M.; Huddleston Slater, J.J.; Meijer, H.J.; Winkel, E.G.; van Winkelhoff, A.J. Implant decontamination during surgical peri-implantitis treatment: A randomized, double-blind, placebo-controlled trial. J. Clin. Periodontol. 2013, 40, 186-195. [CrossRef]

34. de Waal, Y.C.; Raghoebar, G.M.; Meijer, H.J.; Winkel, E.G.; van Winkelhoff, A.J. Implant decontamination with 2\% chlorhexidine during surgical peri-implantitis treatment: A randomized, double-blind, controlled trial. Clin. Oral Implant. Res. 2015, 26, 1015-1023. [CrossRef]

35. Becker, K.; Brunello, G.; Scotti, L.; Drescher, D.; John, G. Efficacy of 0.05\% Chlorhexidine and 0.05\% Cetylpyridinium Chloride Mouthwash to Eliminate Living Bacteria on In Situ Collected Biofilms: An In Vitro Study. Antibiotics 2021, 10, 730. [CrossRef]

36. Elmore, S. Apoptosis: A review of programmed cell death. Toxicol. Pathol. 2007, 35, 495-516. [CrossRef]

37. Zhang, Y.; Chen, X.; Gueydan, C.; Han, J. Plasma membrane changes during programmed cell deaths. Cell Res. 2018, 28, 9-21. [CrossRef]

38. Cummings, B.S.; Wills, L.P.; Schnellmann, R.G. Measurement of cell death in Mammalian cells. Curr. Protoc. Pharmacol. 2012, 56. [CrossRef]

39. Krampe, B.; Al-Rubeai, M. Cell death in mammalian cell culture: Molecular mechanisms and cell line engineering strategies. Cytotechnology 2010, 62, 175-188. [CrossRef]

40. Subramani, K.; Wismeijer, D. Decontamination of titanium implant surface and re-osseointegration to treat peri-implantitis: A literature review. Int. J. Oral Maxillofac. Implant. 2012, 27, 1043-1054.

41. Caiazzo, A.; Canullo, L.; Pesce, P. Consensus Report by the Italian Academy of Osseointegration on the Use of Antibiotics and Antiseptic Agents in Implant Surgery. Int. J. Oral Maxillofac. Implant. 2021, 36, 103-105. [CrossRef]

42. Solderer, A.; Kaufmann, M.; Hofer, D.; Wiedemeier, D.; Attin, T.; Schmidlin, P.R. Efficacy of chlorhexidine rinses after periodontal or implant surgery: A systematic review. Clin. Oral Investig. 2019, 23, 21-32. [CrossRef]

43. Kotsakis, G.A.; Lan, C.; Barbosa, J.; Lill, K.; Chen, R.; Rudney, J.; Aparicio, C. Antimicrobial Agents Used in the Treatment of Peri-Implantitis Alter the Physicochemistry and Cytocompatibility of Titanium Surfaces. J. Periodontol. 2016, 87, 809-819. [CrossRef] [PubMed]

44. Chellini, F.; Giannelli, M.; Tani, A.; Ballerini, L.; Vallone, L.; Nosi, D.; Zecchi-Orlandini, S.; Sassoli, C. Mesenchymal stromal cell and osteoblast responses to oxidized titanium surfaces pre-treated with $\lambda=808 \mathrm{~nm} \mathrm{GaAlAs} \mathrm{diode} \mathrm{laser} \mathrm{or} \mathrm{chlorhexidine:} \mathrm{In} \mathrm{vitro}$ study. Lasers Med. Sci. 2017, 32, 1309-1320. [CrossRef]

45. Song, I.S.; Lee, J.E.; Park, J.B. The Effects of Various Mouthwashes on Osteoblast Precursor Cells. Open Life Sci. 2019, 14, 376-383. [CrossRef] [PubMed]

46. Markel, J.F.; Bou-Akl, T.; Dietz, P.; Afsari, A.M. The Effect of Different Irrigation Solutions on the Cytotoxicity and Recovery Potential of Human Osteoblast Cells In Vitro. Arthroplast. Today 2021, 7, 120-125. [CrossRef] [PubMed]

47. Park, Y.; Huh, K.M.; Kang, S.W. Applications of Biomaterials in 3D Cell Culture and Contributions of 3D Cell Culture to Drug Development and Basic Biomedical Research. Int. J. Mol. Sci. 2021, 22, 2491. [CrossRef]

48. Kapałczyńska, M.; Kolenda, T.; Przybyła, W.; Zajaczkowska, M.; Teresiak, A.; Filas, V.; Ibbs, M.; Bliźniak, R.; Łuczewski, Ł.; Lamperska, K. 2D and 3D cell cultures-A comparison of different types of cancer cell cultures. Arch. Med Sci. AMS 2018, 14, 910-919. [CrossRef]

49. Chen, E.P.; Toksoy, Z.; Davis, B.A.; Geibel, J.P. 3D Bioprinting of Vascularized Tissues for in vitro and in vivo Applications. Front. Bioeng. Biotechnol. 2021, 9, 664188. [CrossRef]

50. Grosso, A.; Burger, M.G.; Lunger, A.; Schaefer, D.J.; Banfi, A.; Di Maggio, N. It Takes Two to Tango: Coupling of Angiogenesis and Osteogenesis for Bone Regeneration. Front. Bioeng. Biotechnol. 2017, 5, 68. [CrossRef]

51. Saran, U.; Gemini Piperni, S.; Chatterjee, S. Role of angiogenesis in bone repair. Arch. Biochem. Biophys. 2014, 561, $109-117$. [CrossRef] [PubMed]

52. Rafii, S.; Butler, J.M.; Ding, B.S. Angiocrine functions of organ-specific endothelial cells. Nature 2016, 529, 316-325. [CrossRef] [PubMed]

53. R Core Team. R: A Language and Environment for Statistical Computing; R Core Team: Vienna, Austria, 2021. 